\title{
PEREMPUAN DALAM SWARA SESTRA DAN FAKTA PERKAWINAN ENDOGAMI ARISTROKAT JAWA
}

Women in Swara Sestra and Facts of Endogamy Marriage in Javanese Arictocrat

\section{Fajar Wijanarko}

Museum Negeri Sonobudoyo Yogyakarta

Pos-el: widjanarko.fajar@gmail.com

\section{Naskah Diterima 5 Februari 2018 -Direvisi Akhir 31 Mei 2018 -Disetujui 31 Mei 2018} doi: doi.org/10.26499/jentera.v7i1.606)

\begin{abstract}
Abstrak: Pada umumnya, perempuan Jawa bercitra baik sehingga kerap dimunculkan sebagai bentuk ajaran dalam sastra. Akan tetapi, dalam teks Swara Sěstra justru dimetaforakan sebagai daun senthe, yaitu alegori perempuan muda yang dimadu dengan perempuan yang lebih tua. Persoalan ini menjadi rumit ketika keadaan tersebut terjadi di lingkungan aristokrat Jawa. Berbekal disiplin filologi dengan metode penyuntingan teks dan penerjemahan, fenomena perempuan dalam teks Swara Sěstra akan diungkapkan. Telaah teks secara semiotik melalui pembacaan heuristik dan hermeneutik kemudian menjadi upaya dalam menafsirkan teks. Pada akhir pembahasan, diketahui bahwa alegori perempuan sebagai senthe merujuk pada citra perempuan Jawa yang tidak baik. Di balik pemaknaan teks tersebut kemudian ditemukan pula bukti bahwa pengalegorian perempuan ini menyeret fakta sejarah tentang maraknya perkawinan endogami di lingkungan bangsawan. Bahkan perilaku tersebut merupakan hal yang subur, terutama di lingkungan dalam tembok istana.
\end{abstract}

Kata-kata kunci: senthe, alegori perempuan, perkawinan endogami, filologi

Abstract: In general, Javanese women are well-imagery and often raised as a form of teaching in literature. However, in the Swara Sëstra text, it is actually metaphorically as a senthe leaves, the allegory of young women who being a co-wife to older women. This issue becomes complicated when the situation occurs in the aristocratic environment of Java. By the discipline of philology with methods of text editing and translation, the phenomenon of women in the text of Swara Sěstra will be expressed. The semiotic study of text through heuristic and hermeneutical readings then becomes an attempt at interpreting the text. At the end of the discussion, it is known that female allegory as a senthe refers to the image of poor Javanese women. Behind the meaning of the text is then found also evidence that this female allegedly dragged historical facts about the rampant endogamy marriage in the nobility. Even the behavior repeatedly happen, especially in the inner court environment.

Keyword: senthe, woman allegory, endogamy marriage, philology

How to cite: Wijanarko, Fajar. (2018). Perempuan dalam Swara Sestra dan Fakta Perkawinan Endogami Aristokrat Jawa. Jentera: Jurnal Kajian Sastra, 7 (1), 1-19. Doi: https://doi.org/10.26499/jentera.v7i1.606 


\section{PENDAHULUAN}

Perempuan adalah sakti. Sosoknya diibaratkan sebagai kekuatan aktif dewa dan dipersonifikasikan sebagai istri (Zoetmulder, 2011: 986). Di dalam teks Manusmrti, perempuan secara kompleks diibaratkan sebagai pelita rumah tangga yang memenuhi darma dari kesatria. Bahkan, pada bait XXIX, dilukiskan bahwa anak-anak, upacara agama, pengabdian yang setia, kebahagiaan, surga leluhur dan pribadi, kesemuanya berada di telapak tangan perempuan ${ }^{1}$ (Wahyono, 2004: 80).

Pelbagai catatan mayor tentang perempuan telah direkam secara apik dalam memori kolektif masyarakat Jawa. Perempuan dalam catatan sejarah Nusantara telah terdengar kiprahnya sejak abad VII. Era Kalingga, sebuah kerajaan tertua di Jawa, mencatatkan Putri Shima sebagai perempuan penguasa kerajaan sejak tahun 647 M. Pada abad X, Ganapriya Dharmapadni, perempuan keturunan raja Jawa Timur, Sri Makuthawangsa Wardhana, memerintah di Bali. Periode berikutnya, era Majapahit pada tahun 1328 - 1350, Tri Buwana Tunggadewi menduduki takhta kerajaan menggantikan ayahnya, Jayanegara. Sementara itu, di tahun 1429-1477 Suhita turut mencatatkan namanya dalam sejarah sebagai perempuan kedua yang memerintah di Majapahit, menggantikan ayahnya, Wikramawardhana (Soekmono, 1993: 71; 78).

Catatan mengenai perempuan tampaknya tidak berhenti pada memori sejarah Nusantara. Pada kenyataannya, perempuan turut memengaruhi pertumbuhan karya sastra, terutama kesusastraan Jawa. Motif-motif tentang perempuan pada satu periode pra-1755 sangat subur untuk diproduksi --seperti halnya tokoh Dewi Indumati dalam Kakawin Sumanasāntaka yang mencari pasangan hidup melalui gelar sayembara. Pada cerita tersebut, akhirnya Pangeran Aja-lah yang dipilih oleh Dewi Indumati sehingga mengakibatkan semua raja peserta sayembara kecewa. Kisah Kencana Wungu dalam Serat Damar Wulan pun menjadi perhatian. Perempuan (Dewi Kencana Wungu) mencerminkan sebagai sosok yang mampu memegang kekuasaan sebagai raja Majapahit. Pada karya sastra yang lebih muda, Serat Babad Mangir, digambarkan Retna Pembayun

\footnotetext{
1 “Apatyam dharmakāryāni, çuçrūşā ratiruttama dārādhīnastathā swargah, pitrinām atmanaçca ha” Anakanak, upacara agama, pengabdian yang setia, kebahagiaan, surga para leluhur dan pribadi, semua itu ada di telapak tangan wanita (Manusmrti: XXIX) (Wahyono, 2004: 80).
} 
yang bertindak sebagai utusan negara (raja) sekaligus orang tuanya dalam melumpuhkan Ki Ageng Mangir, pemberontak pada masa tersebut (Suwarni, 1996: 361-368).

Kenyataan yang sama terjadi pula pada teks-teks produksi kerajaan Jawa setelah tahun 1755. Perempuan dirasakan masih menarik untuk dikisahkan. Yasadipura (1939) dalam kajiannya mengenai Serat Menak Ngrajak turut menceritakan kuasa perempuan melalui tokoh Dewi Kuraisin. Ia adalah putri dari Jayengrana dan Ismayati yang memimpin 40 prajurit jin perempuan dalam medan laga dalam menegakkan kebenaran. Beberapa tokoh lainnya, seperti Dewi Kelaswara dan Dewi Rengganis dalam Serat Menak Cina, juga turut menjadi perhatian sebagai figur prajurit perempuan yang mandiri (Yasadipura, 1933). Pada tema-tema moral pendidikan, teks dengan khazanah keperempuanan banyak mewarnai keberagaman kesusastraan Jawa. Sebut saja Niken Tambangraras dalam teks Centhini. Ada lagi teks Wulang Putri, Wulang Wanita, Wulang Wanodya, Wulang Pawestri, Wulang Estri, dan Candrarini, yang seluruhnya menjadi dokumen ajaran kepada perempuan. Menakjubkannya lagi, ternyata persebaran teks-teks tersebut tidak hanya terjadi di skriptorium keraton-keraton Jawa, tetapi juga di perpustakaan-perpustakaan penyimpanan naskah (Behrend, 1990: 790-791; Girardet, 1983: 1019; Jandra, 1987: 7). Penggambaran perempuan dalam pelbagai teks tersebut tidak terbatas pada cerminan atas seksualitas dirinya, tetapi berdiri pada peran-peran ganda, baik normatif, substantif, dan prestatif (Suwarni, 1996: 2).

Meskipun penggambaran perempuan dengan citra baik banyak dijumpai dalam karya sastra, nyatanya ditemukan pula cerita minor atas dirinya. Ada kalanya perempuan berada dalam konstruksi normatif yang diagungkan, tetapi ada kalanya sebaliknya. Salah satu cerita minor perempuan terdapat dalam teks Swara Sestra. Naskah Swara Sěstra (selanjutnya disebut SS) koleksi Pakualaman (kode koleksi St. 93) merupakan naskah tunggal yang terdiri atas 18 teks berbeda. Teks SS merekam pelbagai hal, termasuk kisah mengenai perempuan yang distilisasi sebagai bentuk ajaran. Perempuan-perempuan yang diceritakan pada umumnya bersifat konform, yaitu menerima terhadap konsekuensi masyarakat dan budayanya. Sosoknya patuh pada sistem sosialnya dengan tidak banyak memiliki ruang gerak (Sadli, 1982: 155). Suryani (2017) mempertegas bahwa perempuan tidak hanya konform, tetapi juga bersifat introvert sehingga memiliki kecenderungan untuk memusatkan pikiran dan perhatian pada diri sendiri. Kecenderungan inilah yang membuat perempuan bereaksi melalui hatinya bukan tindakannya (Suryani, 2017: 183). 
Akibat dari keadaan demikian, perempuan tidak adanya ruang negosiasi bagi perempuan. Kondisi perempuan seperti ini umumnya berhubungan dengan keterikatan dirinya dengan latar belakang, lingkungan, cara pandang, dan tujuan masyarakat secara luas (Suryani, 2017: 184). Salah satu contoh situasi yang menekan perempuan adalah penggambaran dirinya dalam teks SS. Perempuan dengan kondisi yang harus rela dimadu tanpa mampu menawar keadaan. Konsekuensinya adalah perempuan muda yang dimadu dengan perempuan yang lebih tua kemudian diumpamakan sebagai senthe.

Metafora senthe diadopsi oleh penulis teks (carik) merujuk pada kenyataan daun senthe yang memberi rasa gatal. Kondisi ini menjadi gambaran dari kondisi sosial masyarakat di dalam teks sebagai masyarakat yang melabeli maru sebagai perempuan yang salah. Sebuah label yang tidak dapat ditolak sebab telah disepakati secara bersama sebagai konvensi yang ada. Di samping itu, metafora perempuan sebagai senthe menghadirkan fakta tentang perkawinan endogami di kalangan bangsawan. Hal ini kemudian membawa pemahaman bahwa teks sebagai sastra merupakan bagian dari dokumen sejarah yang perlu ditafsirkan. Di dalamnya terdapat kecerdasan universal dari tanda-tanda sosial, budaya, hingga politik pada masanya yang mampu ditelaah oleh masyarakat setelahnya (Miller, 2011: 13).

Kajian terhadap teks SS selanjutnya mengedepankan disiplin ilmu filologi dengan metode penyuntingan teks dan penerjemahan. Penyuntingan teks didasarkan pada metode filologi klasik dengan mengalihaksarakan teks dengan memberi catatan yang kurang sesuai. Sementara metode penerjemahan dilakukan dengan menerjemahkan secara leksikal. Tahap berikutnya adalah pembacaan teks secara heuristik dan hermeneutik, yaitu menafsirkan maksud teks dan menyejajarkannya dengan bukti sejarah yang ada. Hal ini kemudian menyeret fakta terkait perkawinan endomagi di kalangan bangsawan yang telah dicatat oleh peneliti terdahulu. Bagian inilah yang kemudian dipahami sebagai bentuk telaah terhadap teks Swara Sěstra.

\section{LANDASAN TEORI}

Pada umumnya, tradisi penulisan sastra klasik terbagi atas dua bentuk, babad dan serat. Tidak ada kaidah yang pasti yang membedakan penulisan babad ataupun serat. Keduanya dapat ditulis dalam bentuk prosa maupun puisi. Pada ulasan ini, teks objek SS merupakan serat dengan kaidah metrum macapat sebagai pola penulisannya. 
Pembicaraan terhadap teks objek terlebih dahulu dimulai dalam cara pandang teks sebagai sastra. Sastra dimaknai sebagai ekspresi satuan yang dibangun atas hubungan antara tanda dan makna, antara ekspresi dan pikiran, antara aspek luar dengan aspek dalam (Faruk, 2012: 77). Sastra, sebagai sistem tanda, mengekspresikan sesuatu secara tidak langsung. Kondisi ini semakin kompleks pada sistem penulisan serat yang didasarkan pada keteraturan metrum. Aturan metrum pada bentuk puisi tembang mengharuskan penulis melakukan pemilahan diksi guna memenuhi bentuk baku yang disepakati. Bahasa yang digunakan pun memiliki tata bahasa khusus dan sering kali menggunakan kata-kata di luar bahasa sehari-hari. Keadaan ini oleh Riffatere diformulasikan sebagai bentuk pengekspresian konsep dan benda-benda secara tidak langsung. Secara sederhana bisa dikatakan bahwa karya sastra (puisi) mengatakan satu hal yang berarti hal lain (Riffaterre, 1978: 1). Hal ini terjadi karena selain kaidah metrum yang mengikat, bahasa dalam puisi cenderung bersifat hati-hati dan padat, tetapi harus memberikan informasi secara luas (Altenbernd dan Leslie, 1970: 9).

Terlepas dari pemahaman sastra, penelitian teks tidak terlepas pada disiplin ilmu filologi. Di awal pertumbuhan studi filologi Eropa, para filolog berkewajiban untuk mencari teks terdekat dari arketip yang terkandung pada naskah saksi dengan membandingkannya. Cara kerja demikian selanjutnya dikenal dengan metode stema (Barried, 1994: 110). Munculnya metode stema disebabkan maraknya proses penyalinan naskah secara terbuka, bukan semata-mata merupakan reproduksi mekanis, melainkan juga proses kreatif. ${ }^{2}$ Kratz berpendapat bahwa kondisi tersebut menyebabkan para filolog lebih menyukai penyuntingan satu naskah secara kritis daripada penyuntingan beberapa naskah --kecuali keadaan naskah yang memaksa untuk dibandingkan secara hybrid dengan catatan harus menyesuaikan kondisi objek (Jandra, 1987: 15-16).

Di dalam cara pandang Indonesia, filologi merupakan disiplin ilmu bahasa yang mendasarkan kerjanya pada bahan tertulis. Hal ini sesuai dengan definisi yang dibangun di Belanda dan Inggris tentang keilmuan filologi yang mengedepankan kesusastraan sebagai objek penelitiannya. Istilah ini kemudian berkembang pesat di dunia Barat sejak

\footnotetext{
${ }^{2}$ Reproduksi kreatif teks terlihat pada penulisan Hikayat Melayu oleh Sultan Melaka dalam mukaddimah yang ditulis oleh Tun Muhammad minta agar diperbaiki (Jandra, 1987: 16). Kemudian, Ramayana Kakawin yang penggarapannya berdasarkan 5 buah naskah, baik Jawa maupun Bali masing-masing saling menunjukkan perbedaan (Kern 1900). Perbedaan tersebut diduga muncul akibat tradisi penyalinan yang mengikutsertakan hasil pembacaan teks lain (Barried, 1994: 115). Dengan demikian, reproduksi kreatif di dalam teks sejatinya tidak dapat dipungkiri.
} 
abad ke-19. Kajiannya pun berkembang meliputi juga studi kebahasaan. Berdasarkan pemahaman yang telah dibangun, maka tujuan mendasar dari kerja filologi adalah mengungkapkan makna teks dalam segi kebudayaan (Baried, dkk., 1994; Fathurrahman, 2015).

Disiplin filologi sebagai studi tentang kesusastraan selalu membangun pengalaman melalui studi kepustakaan (Wahjono, 2004: 73). Hal ini menjadi bagian dari kerja kualitatif dengan mengedepankan sumber-sumber baik primer maupun sekunder sebagai motor dari penelitian. Selanjutnya, penelitian filologi dimaknai pula sebagai konfigurasi keahlian ilmiah dalam mengurasi teks historis. Dengan kata lain, kerja utama seorang filolog adalah mengidentifikasi dan merestorasi teks dari setiap masa lampau kultural (Sudibyo, 2007: 108). Mekanisme kerja inilah yang memaksa filolog untuk melakukan persejajaran antarsumber guna memperkaya cara pandang. Namun, itu tidak berarti pola-pola konvensional filologi, suntingan teks dan terjemahan kemudian lantas ditinggalkan. Justru tahapan tersebut menjadi pintu gerbang dari pembacaan masa lampau. Bahkan, pada fase tersebut, jurang bahasa dan budaya mampu dipersempit. Dengan kata lain, pembaca di luar teks mampu mengilustrasikan maksud dari pujangga dan teks itu sendiri (Wulandari, 2014: 69).

Kendati demikian, telaah teks $S S$ mengedepankan pendekatan filologi modern, dengan tetap melakukan penyuntingan teks dan penerjemahan. Selanjutnya, teks sebagai sastra ditelaah secara semiotik sesuai dengan cara pandang Riffaterre. Pembacaan sastra ini dilakukan secara bertahap. Yang pertama adalah pembacaan secara heuristik dengan menafsirkan teks terlebih dahulu. Kemudian, pembacaan kedua secara hermeneutik, dengan mengaitkan beberapa sumber pendukung sebagai upaya telaah sastra secara komprehensif.

Di samping pembacaan teks sebagai sastra dan filologi, penelusuran identitas zaman penulisan teks pun perlu dilakukan. Hal ini nantinya akan berkaitan dengan kondisi sosial kultural di era raja yang bertakhta. Melalui narasi sosio-kultural pembentukan teks, pembaca akan dengan mudah menyelami makna cerita. Akan tetapi, kenyataannya pada teks $S S$ tidak ditemukan tarikh apa pun. Teks gelap tanpa informasi seperti ini menuntut untuk diteliti dengan menggunakan pendekatan kodikologi dan paleografi aksara. Kedua pendekatan tersebut menjadi langkah strategis dalam menentukan informasi dari sumber-sumber eksternal. Langkah sederhana melalui 
pendekatan kodikologi adalah dengan membandingkan unsur-unsur yang membentuk naskah, seperti media tulis, penjilidan, hingga iluminasi dan ilustrasi dalam teks. Sementara itu, secara paleografi, teks gelap dapat dibandingkan dengan paleografi teks yang bertarikh lengkap. Dengan demikian, perbandingan corak aksara akan melahirkan hipotesis yang terang atas teks tersebut (Fakhriati, 2012: 50)

Di luar pembicaraan tentang disiplin ilmu sebagai pendekatan terhadap teks, dipahami pula bahwa kandungan isi teks menjadi pembahasan tersendiri. Pada teks objek, perempuan memegang peranan penting dalam cerita. Perempuan selalu dikaitkan dengan etika dan kesopansantunan. Perempuan selalu disoroti keindahan, kelembutan, dan kerendahan hatinya, baik secara jasmani maupun rohaninya (Kartono, 1977: 29). Pandangan Jawa melukiskan perempuan utama sebagai sosok yang mrakati, gumati, dan luluh. Mrakati berarti membangun sifat keindahan dan memperlihatkan rasa manis, baik dalam bersikap maupun bertutur. Gumati berarti memelihara dan merawat, tidak hanya dirinya tetapi juga lingkungannya, termasuk pula gumati terhadap diri, secara lahiriah dan batiniah. Luluh berarti ajering manah atau tentang sistem pengendalian hati dan rasa egois yang berlebihan (Jandra, 1987: 191-192).

Selanjutnya, konsekuensi dari kesepakatan terhadap citra perempuan tersebut berdampak pula pada bentuk negasinya. Perihal tersebut direkam dalam teks Nitipraja yang mengibaratkan perempuan adalah bentuk goda dari seorang pemimpin.

Sampun arakèt lawan pawestri/ jroning pura yeku madu wisa/ estri purusa karsanel estri salokanipun/ tirta suda sěgara gěni/ bahni wrěksa angarang/ puspa wiguneku (...) (Nitipraja, 38-39)

'Jangan dekat dengan wanita dalam istana, itu madu (sekaligus) racun. Wanita itu nafsu kehendaknya. Wanita itu perumpamaannya bagai air yang menyusutkan lautan api, api yang membuat kayu menjadi arang. Itu adalah bunga yang pandai. (Wulandari, 2006: 75).

Persoalan tersebut oleh Chalil (1977) diejawantahkan dalam bentuk klasifikasi kelompok perempuan. Perempuan dalam struktur sosial masyarakat dikelompokkan dalam 3 golongan: yang dihinakan, didewakan, dan disetarakan. Kendati perempuan berada pada golongan didewakan dan disetarakan, Ki Hajar Dewantara tidak sependapat dengan pandangan itu. Dewantara (1994: 237) lebih menekankan bahwa perempuan haruslah diluhurkan. Kesetaraan yang dimaksud tidak lantas serupa dan benar-benar sejajar dengan laki-laki. 
"Persamaan hak antara laki-laki dengan perempuan itu belumlah mengandung arti bahwa seorang perempuan boleh menjalankan tingkah laku dari laki-laki. Sering perempuan tidak bisa meniru perbuatan laki-laki karena bukan kodratnya. Kalau mereka melakukan juga, boleh jadi akan berbahaya untuk kesehatan tubuhnya" (Dewantara, 1994: 237).

Dengan kata lain, perempuan berada pada kondisi yang diperhatikan sekaligus menyakitkan. Berbagai pelabelan terhadap dirinya dengan sangat mudah melekat. Keadaan ini tidak mengejutkan sebab perempuan adalah penerus wangsa. Perempuan adalah wujud substitusi dari seorang laki-lakinya, seperti sakti dari kedewataan sang dewa.

\section{HASIL DAN PEMBAHASAN}

\section{Penelusuran Teks Swara Sestra}

Tradisi sěstra di Pakualaman telah dimulai sejak era Pangeran Natakusuma, Paku Alam I. Sosok Adipati gemar mempelajari sastra karena membawa kebahagiaan. Falsafah sěs sebagai manifestasi dari rasa yang tinggi dan tra adalah sarana nyata menjadi identitas sastra kadipaten tersebut. Sěstra selanjutnya mampu memberi pandangan tentang perwujudan sarana nyata dari rasa yang tinggi. ${ }^{3}$ Konsep yang menekankan pada kemauan dan kemampuan penguasaan diri. Termasuk di dalamnya adalah laku untuk mempertajam akal budi sebagai pedoman dari keluarga kadipaten (Saktimulya, 2013: 70; 2016: 6). Penulisan dan penyalinan teks di kadipaten mencapai puncaknya pada era Paku Alam II. Kondisi ini terjadi karena Paku Alam I menitikberatkan pemerintahan pada urusan politik, sedangkan pada pemerintahan Paku Alam II ${ }^{4}$ gejolak politik cenderung tenang. Dengan demikian, Suryaningrat (Paku Alam II, yang naik takhta pada 4 Januari 1830) memiliki keleluasaan dan ruang yang tenang untuk memperdalam sěstra sebagai keilmuan batin, bekal kekuatan hati untuk mencapai kemuliaan (Dewantara, 1994: 288 — 292; Saktimulya, 2016: 5).

\footnotetext{
${ }^{3}$ Dalam kutipan Muhammad Haji Salleh (2013) agaknya benar bahwa sastra (Sěstra) berkaitan langsung pada proses rasa dan penghalusan budi pembacanya, "proses mempertajam atau menghalusi perasaan kemanusiaan seseorang pendengar/pembaca, yang tidak dapat diberikan oleh seni lainnya, sedalam yang ditawarkan oleh sastera." (Salleh, 2013:298).

${ }^{4}$ Di era Paku Alam II (1830-1858), segala pembangunan dan pengembangan kadipaten dilakukan, termasuk usaha dalam memajukan kesusastraan. Berawal dari penggubahan kisah Baratayuda dalam berbagai gambar saat masih menjadi putra mahkota, lantas seusai naik takhta Suryaningrat (Paku Alam II) banyak memproduksi naskah (teks) antara lain Sěstra Agěng Adidarma, Sěstradisuhul, Babar Palupyan, Piwulang Estri (Saktimulya, 2016: 5-6).
}

8 Jentera, 7 (1), 1-20, (C2018 
Teks Swara Sestra, sebagai bagian dari tradisi sěstra produksi kadipaten, erat akan konsep ajaran. Akan tetapi, pada katalog naskah tersebut tidak digolongkan pada subjek piwulang, melainkan sastra. Dari 18 teks yang terdapat di dalam naskah SS, hanya 5 teks yang berbicara persoalan ajaran, ke-13 teks lainnya bercerita tentang sastra (Wijanarko, 2015: 16). Dari ke-18 teks tersebut, dipilih teks ke-14 yang mendokumentasikan persoalan ajaran berumah tangga. Lebih spesifik, pada ungkapan pelabelan perempuan yang dialegorikan sebagai lumbu. Terkait judul naskah swara sěstra ${ }^{5}$ ditemukan pada pupuh Sinom bait I.

Sěstra winarna ngun kawula, ing sakanca kula sami, jrihing kaabdekěn samya, atur pagujěngan gusti, swara sěstra artining, sěstra swara těgěsipun (...) (Swara Sestra: 1)

Diceritakan (ajaran) sěstra padaku, juga pada sesama teman-temaku, (dengan) rasa takut dipersembahkan pada sesama, (yakni bagai) ucapan senda gurau tuan, yang artinya swara sěstra, (ajaran) sěstra (dengan) suara jelasnya (Wijanarko, 2015: 16).

Perlu diketahui bahwa pada penulisan teks Swara Sestra antara tembang satu dan lainnya tidaklah memiliki keterkaitan. Setiap sub-episode tembang berdiri sendiri-sendiri sebagai dokumen yang berbeda-beda. Di sisi lain, bahasa yang digunakan dalam penulisan teks pun beragam, tidak hanya Jawa, tetapi juga Melayu (Saktimulya, 2005: 220). Pascaproses alih aksara ditemukan pula ejaan dalam bahasa Arab, seperti hakullah, dan bahasa Belanda, seperti ridre serta gupremin (Wijanarko, 2015: 20).

Pengembaraan pembacaan teks tidak berhenti pada identitasnya, tetapi juga pada identitas naskah. Tidak ditemui titik terang terkait dengan tarikh waktu penulisan atau identitas carik. Hanya saja, secara kodikologis media kertas Eropa ${ }^{6}$ yang digunakan memiliki identitas seperti pada naskah-naskah di era Paku Alam II. Visual tanda air berupa singa bermahkota dengan pedang menghadap ke samping, dalam medalion bertuliskan PROPATRIA EENDRAGT MAAKT MAGT serta tanda pembanding $V D L^{7}$

\footnotetext{
${ }^{5}$ Judul swara sěstra memanglah ditemukan di dalam teks, namun beberapa etiket memiliki catatan yang berbeda. Pada etiket punggung tertulis judul Sěrat Bab Kadaměl Gěndhing. Pada etiket gantung tertulis Sěrat Pěpěthikan Kadaměl Gèndhing. Kedua etiket tersebut dimungkinkan memiliki relasi dengan judul naskah (padanan judul) yang secara konteks telah mencerminkan isi dari teks Swara Sěstra.

${ }^{6}$ Penyebutan kertas Eropa terkait dengan produksi kertas yang dilakukan di negara tersebut. Kertas dengan watermark dan countermark telah digunakan sejak abad ke-13 di Italia, dan secara umum telah dikenal di Eropa pada abad ke-15 (Pudjiastuti, 2006:14).

${ }^{7}$ VDL adalah akronim dari Van der Ley yang merupakan inisial dari pembuatnya. Kertas-kertas dengan inisial VDL dicetak sejak 1698 - 1815 di Belanda. Dengan kata lain, produksi kertas telah berlangsung 100 tahun lebih, maka tidaklah diragukan kualitas dari media tulis tersebut (Churchil, 1965; Saktimulya, 2016: 86).
} 
mampu menjadi penanda kodikologi adanya rentang waktu yang dekat antarteks yang dituliskan dengan media kertas yang sama.

Berdasarkan akumulasi sumber kodikologi, ditemukan bahwa naskah ditulis kiranya era PA II hingga PA IV. Bukti tersebut belumlah cukup sehingga secara paleografi aksara harus dibandingkan. Pada akhirnya, dari pembandingan tersebut ditemukan bahwa teks Swara Sestra ditulis oleh carik Jayengminarsa. ${ }^{8}$ Hal ini diketahui dari beberapa teks yang digunakan sebagai pembandingnya, terutama teks produksi Jayengminarsa, di antaranya Sěstra Agěng Adidarma, Sěstradisuhul, dan Babad Palupyan. Terdapat pula teks lain, yaitu Kyai Sěstradilaras yang merupakan karya Jayengminarsa di akhir pemerintahan PA III atas perintah PA IV (saat masih menjadi putra mahkota) dan selesai pada awal pemerintahan PA IV (Febriyanto, 2012: 19—20).

Purwaningkang têmbang kidung, karsanira Kangjêng Gusti, kang jumênêng ping sêkawan, saharsa wiwit anganggit, langênira risang Arjuna, satriya lananging bumi. (Kyai Sestradi Laras: 10).

Permulaan kidung tembang, (atas) kehendak Kangjeng Gusti (Paku Alam) keempat yang bertahta, berkeinginan memulai menciptakan tarian risang Arjuna, kesatriya pajantan tangguhnya dunia (Febrianto, 2012: 20).

Berdasarkan hipotesis atas dasar komparasi paleografi beberapa teks, dapat ditarik kesimpulan bahwa teks Swara Sestra diproduksi di akhir masa pemerintahan PA III (Sasraningrat/Suryasasraningrat I) tahun 1858-1864 hingga pada masa pemerintahan PA IV (Nataningprang/Suryasasraningrat II) tahun 1864-1878 (Wijanarko, 2015: 19—20).

\section{Alegori Perempuan}

Begitu banyak teks bertemakan perempuan yang telah ditulis. Motif penulisannya selalu berkaitan dengan nilai sosial dan pendidikan. Kesemuanya berbicara tentang etika, baik definitif maupun aplikatif. Istilah "etika" dapat diartikan sebagai keseluruhan norma dan penilaian yang dipergunakan oleh masyarakat dan bersangkutan dengan manusia dalam menjalankan kehidupannya (Suseno, 1984: 6). Sementara itu, Hadiatmojo (2011) menyatakan etika sebagai ilmu yang berkaitan dengan perbuatan yang baik dan tidak baik sejak dalam akal dan pikiran. Nilai-nilai etika Jawa meliputi etika hubungan manusia

\footnotetext{
8 Jayengminarsa merupakan penulis teks Sěstradisuhul. Pada pupuh Sinom tertulis 'dene abdine kang (ng)garap, wusdene ingkang ngladosi. Den Panji Jayengminarsa, craki pěthěl těměn tabri'. Abdi yang mengerjakan dan juga melayani adalah Raden Panji Jayengminarsa yang sangat rajin dan bersungguhsungguh (Saktimulya, 2016: 107).
}

10 | Jentera, 7 (1), 1-20, (C2018 
dengan Tuhan, dan sesama manusia. Kecenderungan etika merupakan aturan yang diejawantahkan sebagai norma dan konvensi, disepakati serta diberlakukan di masyarakat (Hadiatmojo, 2011: 9; 24).

Berbicara mengenai etika, perempuan Jawa berhubungan erat dengan etika dan kesopansantunan. Perempuan selalu disoroti keindahannya. Pribadinya menyandang predikat lembut dan rendah hati (Kartono, 1977: 29). Predikat ini kemudian melahirkan stigma Jawa bahwa perempuan adalah individu yang luluh, yang berarti ajering manah -sebuah sistem pengendalian hati dan rasa egois yang berlebihan. Perempuan pun berhubungan langsung dengan idiom bangkit miranteni, yaitu sibuk untuk melengkapi kebutuhan seisi keluarga (Jandra, 1987: 192). Hal ini adalah bagian dari darma gumati yang dilakukan perempuan sebagai istri sekaligus ibu.

Citra perempuan apik pada masyarakat Jawa menjadi sebuah sekat norma yang tidak bisa dilanggar. Kecenderungan ini dibangun sesuai dengan pemahaman narimah, sumarah, dan ririh-ruruh dalam ujarannya. Perempuan bukan individu yang terbuka, sosoknya hidup dalam aturan, seperti terlihat pada kutipan berikut.

Kuněng ing pangrěngganira, sěněng ing sir sami ěsir, sir ing estri lawan priya, tan kenging dipun kètawis, lawan dugi prayogi, tanpa wangěning pangugung, sampun dede kinantha, kantha-kanthi kanthetaning, ning nakono andadekna onang-onang (Swara Sestra: 1$)$.

Terjemahan:

Sebabnya dijadikan perhiasannya, (yang) senangnya saling menaksir menaksirnya wanita kepada lelaki, tidak boleh diperlihatkan, dengan mupakat agar supaya baik, tiada batas dalam pujiannya sudah tidak (dapat) digambarkan, bentuk, wujud, yang selalu mengikat, demikian itu yang menjadikan kasmaran.

Perempuan yang memiliki rasa kasih pada seorang laki-laki, tidaklah bijak untuk diperlihatkan. Meskipun begitu besar, sosok perempuan Jawa bukanlah pribadi yang agresif, melainkan pribadi yang luruh. Norma sosial ini bukan berarti membangun pandangan anti feminisme, tetapi lebih menempatkan perempuan secara kultural sebagai individu yang lemah lembut, emosional, dan keibuan (Fakih, 2012: 8). Label lemah lembut inilah yang menempatkan perempuan Jawa sebagi pribadi yang luhur, dengan berbagai dampak yang ditimbulkannya. Terlebih lagi apabila dipahami bahwa perempuan dimaknai sebagai gender dengan sifat menonjol yang melekat pada dirinya (Fakih, 2012: 15). 
Kartono (1977: 32-33), menggambarkan perempuan sebagai sosok yang memelihara dan melindungi. Proyeksi sederhana dari anggapan tersebut adalah kemampuan gender ini dalam memelihara dan melindungi kehormatan diri. Bahkan, Jandra (1987: 128) berpandangan bahwa perempuan Jawa adalah sosok pemalu. Sifat malu ini dilakukan oleh perempuan berkaitan dengan kesopanan dalam berhubungan dengan pria. Akan tetapi, kenyataan yang tertulis pada teks justru berbeda. Perempuan, pada pupuh Megatruh bait 15-16, dialegorikan sebagai lumbu atau daun keladi yang justru menjadi buah bibir.

Dadi rěmbuging akeh ngluwihi ewuh, papa sěbutane iki, iya sak dhuwuring ratu, adrěng si lumbu angukih... (16) Wus kaběněring akeh pinacokmau, si lumbu dadi wong cilik, ulihna mring janganipun, denbumboni denrěragi, měksa nyalěkit maring wong.

Terjemahan:

Jadi perbincangan (orang) banyak membuat sangat susah, buruk sebutannya ini, ya (buruknya) melebihi tingginya ratu, (keinginan) si lumbu sangatlah berlebih, ... (16) Sudah benar banyak sindiran tadi, si lumbu jadi orang kecil, kembalikanlah pada sayurnya, dibumbui (dan) diberi ragi, tetap menggigit (rasanya) orang.

Metafora 'sak dhuwuring ratu' mendefinisikan tentang keburukan yang sangat. Perempuan sebagai buah bibir adalah catatan merah bagi dirinya. Terlebih lagi pada bait tersebut disebutkan bahwa si lumbu dijadikan orang kecil. Hal ini mengisyaratkan tentang strata sosial masyarakat pada zamannya. Masyarakat di masa pemerintahan PA III dan PA IV masih erat dengan hierarki sosial. Maka, tidak mengherankan jika pada masa itu tumbuh istilah ningrat bangsawan dan rakyat. Hal tersebut secara implisit didukung dengan munculnya istilah 'dikembalikan pada sayurnya' --istilah yang dapat dimaknai sebagai golongan sosial masyarakat di luar tembok istana.

Di akhir kutipan bait ke-16 muncul kutipan yang mengejutkan, yakni 'denbumboni denrěragi, měksa nyalěkit maring wong.' Bagian ini menandai adanya kegagalan pendidikan norma pada perempuan. Alasan tersebut muncul sesuai dengan kutipan bait ke-18 tentang perempuan yang menjadi madu.

Kayata pocapaning wong wadonipun, rujak senthe saupami, denmaru lan ninekipun, nora wurung anggatěli, la-ilane wis měngkono (Swara Sestra: 18)

Ibarat ucapan seorang perempuannya, diumpamakan rujak senthe, (perempuan) (yang) dimadu dengan neneknya pastilah (menyebabkan) rasa gatal, nasehat leluhur demikian itu.

12 | Jentera, 7 (1), 1-20, (C2018 
Perempuan muda yang dimadu dengan neneknya diumpamakan seperti daun senthe, tumbuhan yang menyerupai kimpul dengan daun menyebabkan gatal (Poerwadarminta, 1939: 550). Sejalan dengan Poerwadarminta, Sudarnadi menyebut senthe (Alocasia macrorrhiza $(L)$ Schott) sebagai tumbuhan berbatang hijau dan tidak dikonsumsi karena menyebabkan gatal (Sudarnadi, 1996: 37).

Perumpamaan inilah yang digunakan untuk menyebut perempuan madu. Perempuan yang akhirnya membuat istri tua (permaisuri) dari seorang raja risi. Padahal, fenomena seperti ini lazim terjadi, bahkan sebelum abad XVIII. Seorang raja memiliki banyak istri, baik sebagai permaisuri maupun selir. Akan tetapi, kejanggalan muncul apabila madunya berasal dari darah ningrat yang sama, keturunan yang berbeda. Perempuan muda menjadi madu dari perempuan yang lebih tua adalah salah. Lebih-lebih potret ini terjadi pada perempuan dengan kedudukan setara, sebagai permaisuri dan permaisuri.

Berbeda halnya ketika perempuan ini berkedudukan sebagai selir. Selir atau klangenan dalem 'kekasih raja' memang jumlahnya tidak terbatas. Tidak tertutup kemungkinan selir-selir baru bermunculan dan berusia lebih muda. ${ }^{9}$ Para permaisuri tidak gusar saat raja menambah banyak selir. Namun, keadaan ini berbalik menakutkan ketika raja mengangkat permaisuri baru. Pendapat ini muncul sebab secara hierarki kerajaan, permaisuri memiliki kedudukan lebih tinggi dibanding selir.

Senthe selanjutnya menjadi alegori negatif bagi perempuan. Kondisi sosial di dalam tembok istana ini terekam dalam catatan metafor juru tulis kerajaan. Peristiwanya sangat jarang dijelaskan secara terbuka, tetapi kerap diungkapkan sebagai sastra wulang. Perlu dipahami juga bahwa perempuan sebagai objek sastra adalah perempuanperempuan aristokrat, setidak-tidaknya perempuan yang berhubungan dengan para bangsawan. Tidak terdapat catatan sejarah bagi masyarakat pribumi di era feodal kerajaan ataupun kolonial. Kalaupun ada, pasti sangat jarang. Dengan kata lain, sastra sebagai representasi simbol sosial hanya berada di dalam ruang lingkup istana. Keraton

\footnotetext{
9 Kondisi demikian lazim terjadi di kerajaan-kerajaan Jawa. Raja pada umumnya memiliki beberapa permaisuri tetapi juga banyak berselir. Pada era Keraton Yogyakarta, Sultan HB II memiliki garwa padmi (permaisuri) berjumlah 4, dengan putra dan putri 80 orang. Istilah klangenan di Keraton Yogyakarta disebut sebagai penggerah-gerah sehingga catatan mengenai selir tidak banyak ditemukan (Mandoyokusumo, 1988: 15).
} 
dalam konteks ini kemudian menasbihkan dirinya sebagai kiblat dari kebudayaan dengan pelbagai misi sejarahnya (Hamengku Buwono X, 2012: 11).

\section{Potret Sosial Masa Penulisan Teks}

Denmaru lan ninekipun menjadi satire dari sejarah perempuan dalam istana. Pembentukan teks diperkirakan pada akhir era pemerintahan PA III hingga awal PA IV (1862-1865). ${ }^{10}$ Pada awal abad XIX, kalangan ningrat memiliki sosial komunitasnya sendiri, termasuk pula asas penerus keturunan darah biru. Perihal sejarah ini berhubungan dengan fenomena perkawinan endogami di lingkungan kerajaan. Keesing dalam Haviland (1985) mengungkapkan bahwa perkawinan antarsaudara dalam keluarga rajaraja pada masa lalu adalah hal yang wajar. Seperti halnya di Mesir, keluarga kerajaan dipandang sebagai setengah dewa. Dewa inilah yang dianggap memiliki wibawa keramat yang menyebabkan tidak berkeinginan untuk menikah dengan golongan manusia. Dengan kata lain, perkawinan di antara mereka berarti melestarikan sifat kedewataan, menjaga keturunan raja sebagai pewaris tahta (Haviland, 1985: 81).

Kenyataan ini tidak hanya terjadi di keraton, tetapi juga di beteng kadipaten. Catatan paling kentara adalah Gusti Kanjeng, calon permaisuri dari calon putra mahkota Paku Alam II. Putra mahkota, Pangeran Nataningprang meninggal mendahului ayahnya, Paku Alam I. Janda Pangeran Nataningprang kemudian dijadikan permaisuri Paku Alam III, dan akhirnya diperistri sebagai permaisuri Paku Alam V. Namanya diabadikan pada beberapa naskah sebagai pemrakarsanya. Pada Babad Tanah Jawi (Bb. 44), nama sang permaisuri disebut bersama dengan calon Paku Alam II. Sedangkan pada Babad Betawi (Bb. 5, Bb. 6, Bb. 7), namanya kembali muncul dengan Paku Alam III. Menariknya lagi, sosok Gusti Kanjeng dengan sangat terbuka dikisahkan pada Babad Betawi (Bb. 4), mengenai kesedihannya atas wafatnya Paku Alam III dan pelbagai nasihat kepada anakanaknya (Saktimulya, 2016: 49).

Kondisi demikian jauh lebih kentara di Keraton Yogyakarta era pemerintahan Hamengku Buwana V. RB. Soedarsono (2006) menuliskan tentang puncak perkawinan endogami di keraton terjadi pada masa setelah Sultan Pesiyar (Soedarsono, 2006: 18). Perkawinan semacam itu begitu pekat di dalam tembok istana. Bahkan, permaisuri

\footnotetext{
${ }^{10}$ Mengenai periode tahun penulisan teks adalah perkiraan atas dasar informasi naskah Kyai Sestradi Laras. Namun, kemungkinan secara pasti belum dapat ditentukan (?).
}

14 | Jentera, 7 (1), 1-20, (C2018 
pertama Sultan V, G.K.R. Kencana merupakan adik sepupu ayahnya yang berarti bibinya. Sementara itu, permaisuri keduanya, G.K.R. Kedhaton adalah sepupunya sendiri (Mandoyokusumo, 1975: 42). Perkawinan antarkeluarga sejatinya merupakan larangan. Akan tetapi, kenyataan ini justru menjadi bentuk dari kenyataan sosial dari masyarakat kerajaan, kaum ningrat. Mereka melakukan perkawinan antarsaudara dengan maksud mempertahankan garis keturunannya. R.M. Dinusatomo dan R.Aj. Musjati adalah cucu dari Hamengku Buwana VIII, tetap melakukan pernikahan antarsaudara sepupu. Lain halnya dengan G.B.P.H. Hadisurya, cucu HB VIII yang menikahi B.R.Ay. Hadisurya, cucu HB VII, yang melakukan pernikahan dengan bibinya. Ada pula perkawinan dengan neneknya, yaitu K.R.T. Danartodipura, piyut HB VI dengan R.Ay. Sitar Tyastuti, cucu HB VI (Soedarsono, 2006: 18). Fenomena ini tampaknya tabu, tetapi perkawinan saudara sesungguhnya menjadi bentuk ritual kedewataan sebagai upaya mempertahankan darah biru bangsawan.

Pada era kolonial, lingkungan sosial dari kerajaan di Yogyakarta itu saling terkait. Komunikasi antarpenguasa pun terjalin harmonis. Sultan HB V, pada malam hari saat Garebeg Sawal (upacara perayaan sedekah raja) selalu mengirimkan sentana (kerabat raja) berserta para penghulu dan sentana Pakualaman untuk menghadap PA II. Mereka diberikan suguhan acara macapatan sebagai bentuk kelestarian tradisi tulis kadipaten (Saktimulya, 2016: 53). Sultan HB V sendiri menyebut PA II dengan sebutan eyang. Kedekatan antara keduanya diwujudkan dengan kunjungan antarkerajaan. Pada kisaran tahun 1833-1855, HB V kerap melakukan kunjungan kepada PA II, begitu pula sebaliknya. Peristiwa tersebut menandakan adanya hubungan kekerabatan yang baik antara keduanya. Bahkan, Sultan mengabarkan bahwa permaisurinya hamil setelah berwisata menyeberangi sungai atas bantuan PA II. Perihal kebaikan ini kemudian dibalas oleh Sultan dengan meminta kepada PA II agar memperkenankan Sultan memangku R.M. Pirngadi (cucu PA II) saat akan dikhitan. Sayangnya, tidak lama kemudian, di tahun 1855, Sultan HB V meninggal saat permaisuri sedang hamil 9 bulan (Saktimulya, 2016: 63).

Berdasarkan fakta kedekatan kesultanan dan kadipaten, silang budaya antara dua kerajaan tidak terhindarkan. Keduanya saling memengaruhi, termasuk pada fenomena perkawinan endogami. Meskipun teks Swara Sestra adalah skriptorium dari Pakualaman, sangat mungkin kritik sosial ini ditujukan untuk kedua kerajaan dan sebaliknya. Pada 
masa kolonial tersebut sangat jarang informasi yang tidak saling mengait. Secara interkultural, kedua kerajaan ini berasal dari akar yang sama sehingga sangat mungkin membangun pola kebudayaan yang serupa.

Di luar pembahasan mengenai kenyataan sosial para bangsawan, terdapat sisi lain dari teks ini. Perempuan dalam kepungan aturan istana senantiasa melakukan penaklukan diri. Sifat inilah yang dimaknai sebagai tindakan konformis. Pribadinya memilih untuk menjadi gumati dan luluh. Bagian cerita perempuan yang konformis oleh Sastronaryatmo (1986) diejawantahkan dalam 4 perkara. Perempuan luhur adalah diri yang mampu bertapa brata, 1) buta, 2) tuli, 3) bisu, dan 4) lumpuh. Tapa brata buta berarti menempatkan suami sebagai satu-satunya sosok yang dilayani. Tapa brata tuli berarti tidaklah mudah percaya terhadap perkataan yang belum menentu kebenarannya, terutama yang menyangkut keluarga. Tapa brata bisu berarti pandai-pandai dalam mengeluarkan perkataan (menjaga perkataan). Tapa brata lumpuh berarti tidak gemar berpergian dan mengejar kesenangan diri pribadi (Sastronaryatmo, 1986: 101).

Berkaitan dengan tapa brata bisu, pada pupuh Megatruh bait 9-10, diungkapkan sebuah ajaran mengenai kebiasaan yang sebaiknya tidak dilakukan oleh perempuan sebagai istri. Perempuan yang beradu pendapat sebaiknya dapat merendahkan egonya dan mengedepankan rasionya. Apabila kondisi tersebut justru terbalik, ego dan emosional yang dikedepankan, maka terjadilah perselisihan dalam hidup 'dadi bedruning wong urip'.

Yen tan rukun dadi gumédrě apadu, mung wruha ala lan běcik, mulane dadekěn prělu, běněr luput ala běcik, ku těpunganing pěpadon. (10) Tan lyan sangking rěbut wicara kang mungguh, ngelmu lawan yudanagri, aja sok anyěngkleng laku, tamtu kěna denukumi, mulane sinaua wong.

\section{Terjemahan:}

Jika tidak rukun jadi bertengkar dan gaduh, yang terlihat (hanyalah) buruk dan baik(nya), oleh karenanya (itu) menjadi penting, benar salah, buruk (dan) baik, (yang) itu bertemu dalam pertengkaran. (10) Tidak lain berasal dari berebut bicara yang terjadi, pengetahuan dan juga sopan santun, (dan) janganlah terbiasa (untuk) memotong pembicaraan, tentu dapat dihukum, karenanya belajarlah (hai) orang.

Jika diperhatikan, kutipan pada bait ke-9 bersifat sangat patriarki. Perempuan berada pada batasan norma istri dan ibu yang menerima. Perempuanlah yang berkewajiban menjaga keharmonisan rumah tangga. Apabila istri tidak rukun, pastilah bertengkar. Inilah yang akan membuat gaduh. Hanya baik dan buruk secara subjektiflah yang tampak pada kondisi demikian. Norma lain yang juga harus dipatuhi adalah adab 
dalam berbicara. Perempuan akan dianggap tidak sopan jika memotong pembicaraan. Sebab inilah yang menjadi asal-muasal dari pertengkaran yang menyudut, yang tidak menemukan jalan keluar 'dadi bedruning wong urip, sangking těpungan měmojok. '

Perempuan dalam kondisi apa pun selalu menjadi perhatian, terlebih di dalam keluarga dengan peran gandanya sebagai istri dan ibu. Keadaan ini terbentuk sebab keluarga adalah kelompok primer terpenting dalam masyarakat (Khairuddin, 1985: 10). Perempuan sebagai istri adalah pribadi yang berperan dalam roda keluarga asih, asah, dan asuh. Adapun perempuan sebagai ibu adalah pribadi pendidik pertama dari segala pendidikan yang diperoleh anak-anaknya. Kodrat mendasar dari ibu yang tidak dapat tergantikan adalah mengandung, melahirkan, dan menyusui. Melalui transfer emosional tersebut, ibu melantarkan sebuah pendidikan yang mendasar kepada anaknya (Jandra, 1987:145-147). Dewantara (1994) menjelaskan bahwa keluarga merupakan bagian terpenting dalam siklus perkembangan anak. Setiap anak mengalami 3 alam pendidikan, yaitu 1) alam keluarga, 2) alam perguruan, dan 3) alam pemuda. Pada alam keluarga, anak menghabiskan waktu lebih lama sehingga peran orang tua dan ibu menjadi penting di dalamnya. Apabila pribadi perempuan yang diteladaninya baik, maka menurunlah sifat itu pada anaknya (Dewantara, 1994: 386).

\section{PENUTUP}

Secara normatif, perempuan tidak berada pada ruang negosiasi yang luas. Perempuan berada pada keadaan yang dikondisikan oleh kesepakatan bersama sehingga kebenaran yang dilakukannya merupakan produk subjektif dari masyarakat. Kondisi ini menuntut perempuan harus terus berlaku baik secara normatif. Apabila perempuan berada pada posisi sebaliknya, maka label minor dengan mudah melekat. Fakta perempuan tentang perempuan yang perilakunya tidak baik digambarkan dalam teks Swara Sěstra. Pada teks ini diperoleh pemahaman bahwa perempuan muda yang dimadu dengan perempuan yang lebih tua adalah kesalahan, meskipun dahulu perempuan dijadikan sebagai selir adalah hal yang wajar. Perempuan demikian selanjutnya diumpamakan sebagai senthe 'daun sente' yaitu perempuan yang membuat gatal. Kenyataan lain menunjukkan bahwa perempuan-perempuan yang dimadu oleh suami atau rajanya lazim ditemukan di dalam lingkungan kerajaan, salah satunya di Yogyakarta. Akan tetapi setelah ditelusuri ternyata terdapat hal yang dianggap tidak pantas. Terlebih ketika ditemukan fakta bahwa 
maraknya perkawinan endogami di kerajaan Jawa, khususnya di Yogyakarta adalah buah dari tindakan demikian.

\section{DAFTAR PUSTAKA}

Alternbernd, Lynn dan Leslie. (1970). A Handbook of The Study of Poetry. London: Macmillan Company.

Barried, Siti Baroroh, dkk. (1994). Pengantar Teori Filologi. Yogyakarta: Seksi Filologi, Fakultas Sastra, Universitas Gadjah Mada.

Behrend. T.E. (1990). Katalog Induk Naskah-naskah Nusantara. Jakarta: Djambatan.

Chalil, Moenawar. (1977). Nilai Wanita. Solo: C.V. Ramadhani.

Churchill, W.A. 1965. Watermarks In Paper. Amsterdam: Menno Hertzberger \& Co.

Dewantara, Ki Hajar. (1994). Karya Ki Hajar Dewantara Bagian I: Pendidikan. Yogyakarta: Majelis Luhur Persatuan Tamansiswa.

Dewantara, Ki Hajar. (1994). Karya Ki Hajar Dewantara Bagian II: Kebudayaan. Yogyakarta: Majelis Luhur Persatuan Tamansiswa.

Fakhriati. (2012). "Perempuan dalam Manuskrip Aceh: Kajian Teks dan Konteks" Jumantara, 3 (1), 44-76.

Fakih, Mansour. (2012). Analisis Gender dan Transformasi Sosial. Yogyakarta: Pustaka Pelajar.

Faruk. (2012). Metode Penelitian Sastra. Yogyakarta: Pustaka Pelajar.

Fathurrahman, Oman. (2015). Filologi Indonesia: Teori dan Metode. Jakarta: Prenada Media Group.

Febrianto, M. Bagus. (2012). Kyai Sěstradi Laras Koleksi Perpustakaan Pura Pakualaman (Suntingan, Terjemahan, dan Analisis Teks). Skripsi S-1. Yogyakarta: Fakultas Ilmu Budaya UGM.

Girardet, Nikolaus. (1983). Descriptive Catalogue of Javanese Manuscripts and Printed Books In The Main Libraries of Surakarta and Yogyakarta. Weisbaden: Franz Steiner Verlag Gmbh.

Hadiatmaja, Sarjana. (2011). Etika Jawa. Yogyakarta: Grafika Indah.

Hamengku Buwono X, (2012). "Peran Istana dalam Tradisi Pernaskahan Nusantara, Pidato Kunci" Warisan Keberaksaraan Yogyakarta: Naskah sebagai Sumber Inspirasi, $1-11$.

Haviland, William A. (1935). Antropologi Jilid 2, terj. R.G. Soekadijo. Jakarta: Erlangga. Jandra. (1987). Dewi Murtasiyah Profil Wanita Tama. Yogyakarta: Javanologi.

Kartono, Kartini. (1977). Psikologi Wanita (Jilid I). Bandung: Penerbit Alumni.

Kern, H., 1900, Râmâyaṇa. Oudjavaansch heldendicht. 'sGravenhage: Nijhoff.

Khairuddin, H. (1985). Sosiologi Keluarga. Yogyakarta: Nurcahya.

Mandoyokusumo. (1975). Serat Raja Putra Ngayogyakarta Hadiningrat. Yogyakarta: Babadan Museum Karaton Ngayogyakarta Hadiningrat.

Miller, J. Hillis. (2011). On Literature Aspek Kajian Sastra. Yogyakarta: Jalasutra.

Poerwadarminta, W.J.S. (1939). Baoesastra Djawa. Batavia: J.B. Wolters' UitgeversMaatschappij.

Riffatere, Michael. (1978). Semiotics of Poetry. Bloomington: Indiana University Press.

Sadli, Saparinah. (1982). Kepribadian Wanita Jawa. Jakarta: PT Gramedia.

18 Jentera, 7 (1), 1-20, (C2018 
Saktimulya, Sri Ratna. (2016). Naskah-naskah Skriptorium Pakualamam Periode Paku Alam II (1830-1858). Yogyakarta: KPG, Ecole Française d'Extrême-Orient, Widyapustaka Pura Pakualaman.

Salleh, Muhammad Haji. (2013). Hikayat Hang Tuah (Jilid 1). Jakarta: Phonix.

Sastronaryatmo, M. (1986). Serat Babad Ila-ila (I-II). Jakarta: Balai Pustaka.

Soedarsono, R.B. (2006). Srimpi Kandha Keraton Yogyakarta, Sebuah Misteri Budaya Genealogi dalam Kehidupan Kaum Ningrat. Solo: ISI Press Solo.

Soekmono. (1993). Pengantar Sejarah Kebudayaan Indonesia II. Jakarta: Penerbit Nasional Trikarya.

Sudarnadi, H. (1996). Tumbuhan Monokotil. Jakarta: Penebar Swadaya.

Sudibyo. (2007). "Kembali Ke Filologi: Filologi Indonesia dan Tradisi Orientalisme" Jurnal Humaniora, 19 (2), 107-118.

Suryani, Elis. (2017). Batari Hyang Janapati dalam Perspektif Gender. Jentera: Jurnal Kajian Sastra. 6 (2), 164-180.

Suseno, Frans Magnis. (1975). Etika Umum Masalah-masalah Pokok Filsafat Moral. Yogyakarta: Penerbit Kanisius.

Suwarni. (1998). "Peranan Wanita dalam Sastra" Kumpulan Karangan Bahasa, Sastra, dan Budaya Nusantara, 356-373.

Wahjono, Parwatri. (2004). "Sastra Wulang dari Abad XIX: Serat Candrarini Suatu Kajian Budaya" Jurnal Makara, Sosial Humaniora, 8 (2), 71-82.

Wijanarko, Fajar. (2015). Swara Sestra (Suntingan Teks dan Terjemahan). Skripsi S-1. Yogyakarta: Fakultas Ilmu Budaya UGM.

Wulandari, Arsanti. (2006). "Wanita dalam Serat Nitipraja" Jurnal Humaniora, 18 (1), $72-78$.

Wulandari, Arsanti. (2014). "Kritik Teks sebagai Gerbang Informasi” Naskah dan Relevansinya dalam Kehidupan Masa Kini. 65-76.

Yasadipura. (1933). Menak Cina. Jakarta: Balai Pustaka.

Yasadipura. (1939). Menak Ngrajak. Jakarta: Balai Pustaka.

Zoetmulder. P.J. (2011). Kamus Jawa Kuna Indonesia. Jakarta: PT Gramedia Pustaka Utama. 